\title{
THE PERSONALITY OF PROFESSOR MVDr. JAN KOLDA
}

\author{
V. KOMÁREK ${ }^{1}$ and O. ŠTĚRBA ${ }^{2}$ \\ ${ }^{1}$ Department of Veterinary Disciplines, University of Agriculture Prague-Suchdol \\ ${ }^{2}$ Department of Anatomy, Histology and Embryology, Faculty of Veterinary Medicine, University of Veterinary \\ and Pharmaceutical Sciences, 61242 Brno \\ Received September 30, 1994 \\ Accepted March 30, 1995
}

\begin{abstract}
$\mathrm{K}$ o $\mathrm{m}$ á r e k V., O. S t e r b a: The personality of Professor MVDr. Jan Kolda. Acta vet. Brno 1995, 64: 5-8.

This paper recalls and highlights the character of Professor Kolda which made him a leading personality of Czechoslovak veterinary morphology in the years between 1928 and 1958.
\end{abstract}

Jan Kolda, personal character, scientific and educational principles

In 1965, on the occasion of the 70th birthday anniversary of the then late Dr. Jan Kolda, Prof. MVDr. Evžen Novotný, Kolda's pupil and later collaborator, compiled his biography. The biography is detailed, elaborate and shows the author's deep sympathy and respect for his professor. It includes many memories of the then still living contemporaries of Prof. Kolda from his native Kamenice near Jihlava and from the later years of his studies. Novotný wellarranged and partly evaluated Kolda's work. The biography appeared as the 5th volume of the series Historia medicinae veterinariae in 1966.

At the occasion of his 100th birthday anniversary we wish to recall Kolda's personal characters, attributes, scientific and educational principles that made him a personality and influenced both his collaborators and pupils.

Professor Jan Kolda was generously endowed with creative, dynamic thinking, an extraordinary memory and, on top of that, he was extremely hard-working and persistent. He was well prepared for his career of university teacher. At first he studied at a secondary school, the so-called gymnasium, in Velké Mezirícíi, then at the University of Veterinary Medicine in Vienna, unfortunately interrupted in 1915 by World War I. After he came home from the war in 1919, he re-assumed his studies of veterinary medicine in provisional veterinarian courses in Prague and then at the newly established University of Veterinary Medicine in Brno. In 1920 he won a scholarship at the distinguished veterinary teaching in Alfort near Paris; here he graduated in veterinary medicine on 14 October 1921 and in tropical veterinary medicine on 28 December 1921. In addition, he studied the 5th and 6th semesters at the Sorbonne Faculty of Medicine in Paris (the first 4 semesters had been accepted) and he passed his doctor's degree examinations in anatomy, physiology and internal medicine. Since he was not granted a scholarship for further studies, he left Paris and came home. After the nostrification of his diploma degree in 1922 he became Professor Rybák's assistant at the Pharmacological Institute of the University of Veterinary Medicine in Brno. In 1923, at this university, he obtained his degree of doctor of veterinary medicine.

His first studies bear evidence of his deep knowledge in many areas (microbiology, physiology, pathological physiology, pathological anatomy and pharmacology) and his liking for experimentation. In 1924 he attended a study stay in Switzerland, in the school year 1924-1925 he was entrusted to substitute the lectures and examinations for Professor Rybák who was then on sick leave, at the same time preparing his habilitation thesis.

And then his life changed fundamentally, he passed over to a completely different subject - to normal anatomy. In his biographies we may read that "he obeyed the invitation of the teaching staff", that "he was asked to occupy the vacant position" etc. We will probably never 
know what really happened. On 1 January 1926 he came to Professor Völker who at that time was head of two anatomical institutes, i.e. of the Faculty of Medicine of the Masaryk University and of the University of Veterinary Medicine. We must not forget that Kolda, at that time aged 31 years, fully absorbed in research and teaching of pharmacology, had to shift to a subject completely different in terms of thinking and methods, that he had to master an enormous amount of information and prepare a new habilitation thesis. In subject and function he linked up with his previous studies on the motoric function of the intestine which appeared in 1926 in nine communications and which dealt with a then virtually unknown area - the anatomy of the abdominal sympathicus in the horse. He introduced an excellent preparation technique and published the results as early as 1927 in three of his probably best anatomical communications. In May 1928 he submitted his habilitation thesis and in September 1928 he was appointed private docent (reader or associate professor) of anatomy.

That was the time when the building of the Department for Normal Anatomy of Domestic Animals was started. Docent Kolda who was acquainted with anatomical institutes in Vienna and Alfort was also sent to Leipzig, Hannover and Brussels. The present department as we know it, the internal arrangement, is completely "Kolda's institute". In 1933 he was appointed extraordinary professor. In his scientific activities Professor Kolda dealt with those areas of veterinary anatomy which he considered to be the least investigated; and that was topographical anatomy of the abdominal cavity of small ruminants, myology of domestic birds and neuroanatomy. Research in topographical anatomy, anatomy of domestic birds and neuroanatomy was carried out at the department during the whole time of his leadership there.

A logical principle of Professor Kolda was that the university teacher should be engaged in scientific activities. He did not want their works to be mere descriptions of anatomical forms, he demanded that the anatomical finding would result in general biological conclusions and that the aspect of development would be respected. He was also a supporter of the theory of the inseparable relationship between the form and function, what he frequently demonstrated using convenient examples.

During the first years of his involvement in anatomy, Professor Kolda was interested particularly in teaching. He built a museum of osteology, the exhibits of which served as a basis for his extensive manual on bones called "Comparative anatomy of domestic animals with regard to the anatomy of man", Part I. General Part, Part 2. The Science of Bones and Cartilages. The book was published in Brno in 1936, it had 913 pages and in scientific circles it spread the renown not only of the author but also of the young University of Veterinary Medicine. In 1937, Professor Kolda was appointed full professor.

One of Professor Kolda's main educational principles was that it is the duty of the university teacher to provide his students with a good textbook. He began to work on the remaining parts during his forced vacations during the Nazi occupation of World War II when all Czech universities and colleges were closed. Parts 3 and 4, The Science of Joints and Muscles, appeared in 1950, but not in the extent is was originally intended. Pictures were based on preparations from the autopsy room and were inspired by pictures from renown textbooks. All the assistants, demonstrators, voluntary workers and technicians were involved in the autopsies and in drawing the pictures. It was not made possible for Professor Kolda to finish the remaining parts as a book. Despite this fact he managed at least to finish the remaining anatomical systems in the form of lecture notes (a form of handouts) in cooperation with his assistants and to publish a book about the anatomy of domestic birds.

Another of his educational principles which he implanted in his students and younger colleagues was: "You will learn the most when you yourself are a teacher!". To speak a world language was something quite natural at that time, and Professor Kolda supported the learning of foreign languages. 
As the only scientist in the branch of anatomy of domestic animals in the then Czechoslovak Republic he undertook the great responsibility for his discipline not only in terms of the outer scientific world, but also within veterinary medicine. That was why he directed instruction to the needs of clinical branches and pathological anatomy but also to hygiene and food technology, not forgetting comparative, functional and developmental anatomy. His responsibility for this branch was convincingly reflected in the high scientific standard of his work and this was how he educated his pupils. He used to say: "Anatomy - that is an ordeal".

As a person he was rather reserved, but he radiated natural authority. Even when dealing with us, the youngest ones, his behaviour was correct and his bearing showed high self-control and inner refinement. As an examiner he was very patient, objective but strict. He was never seen to lose his temper or heard to raise his voice. He had the spirit of a great man. He was incapable of narrow-mindedness, he knew no intrigues, even though he himself was the object of many. As a professional he was not afraid of his collaborators and never envied his pupils their successes. In the years when we were around him, his days were filled with never-ending activity. In the morning he was occupied with teaching and administration, so that his own work was done in the afternoon and evening. His scientific intentions were carried out in the form of dissertation theses of his doctorandi who were engaged in areas that interested him. At that time he prepared lecture notes. As the "landlord" of the department he stayed there virtually all the time and we, his youngest colleagues, were occupied as scribes, noting down his dictations, very frequently until late at night. While dictating the anatomy texts - and that was usually in the library - he used to walk slowly around the long table covered with green cloth standing in the middle of the room, chain-smoking his "Partyzánka" cigarettes. Once in a while he glanced into the books spread out on the table and quietly, but clearly and fluently, dictated. The text was typewritten the following day and required no corrections. In addition, we had to draw the pictures for the texts and books. Compared with the student scientists of today, we spent much more time at the department and our work was much more responsible. The old man never hesitated to involve us in teaching. Our presence at the department and operational meetings was obligatory, so that their was no great difference between an assistant and demonstrator. For many of us the department became our second home, it was the place where we studied and where we went to give information about the results of our examinations, about the successes and failures of our private lives. At important moments Professor Kolda gave his pupils many a valuable piece of advice and, if need be, did not hesitate to defend them against the powerful.

In the last nine years of his life he was a sick man, the last four years he was not even able to do any active work any more and could not follow his plans. His life-long work has never been closed, it is continuing, and not only at the department he had built, but also in many other places.

After his death the department was managed mostly by his pupils: Doc. MVDr. Radim Najbrt CSc., Prof. MVDr. Jiři Kaman DrSc., now by Prof. MVDr. Ceněk Červený CSc. Kolda's work is continuing at other workplaces too, and in other directions he had begun.

Before the war, MVDr.Tomislav Ciliga from the Anatomical Institute in Zagreb, had elaborated his habilitation thesis about the furrows and gyri of the great brain under the leadership of Professor Kolda.

In 1949-1951, MVDr. Marian Chomiak, Head of the Anatomical Institute of the Veterinary Faculty in Lublin and later professor and dean, elaborated his habilitation thesis on neuroanatomy under the direct leadership of Prof.Kolda and he established this discipline at the Anatomical Institute in Lublin.

In 1949, the University of Veterinary Medicine was launched in Košice. Professor Kolda's assistant, MVDr. Peter Popesko, later professor and DrSc., being well-equipped by 
his teacher in terms of scientific knowledge, teaching and literature, moved there to develop morphology. He concentrated on topographical anatomy and gave his students as well as our home and world scientific public excellent atlases, he also elaborated textbooks of anatomy for students of veterinary medicine and animal husbandry. More of Professor Kolda's pupils went to the University of Veterinary Medicine in Košice.

During the Jife of Professor Kolda, many agricultural, veterinary and food-technology secondary and apprentice schools were established where teachers educated and examined by Professor Kolda, what in itself was the best recommendation, took over instruction in anatomy, histology and embryology.

From 1952, anatomy classes for animal husbandry specializations were held at the Department of Anatomy. Prof. Kolda entrusted his assistant, MVDr.Vladimír Komárek (later professor and DrSc.), to teach anatomy. When he left for the University of Agriculture in Prague, another assistant of Prof. Kolda, MVDr. Arnošt Hampl (later professor and CSc.) took his place at the then University of Agriculture in Brno. Anatomical workplaces were founded at both universities, in Prague specialized in the anatomy of domestic birds, in Brno specialized in the anatomy of farm mammals. At both workplaces many textbooks for agricultural apprentice schools were written.

After 1954, the former demonstrator of the Anatomical Institute, MVDr.Vladimír Uhrín (later professor and DrSc.), moved to the Anatomical Institute of the University of Agriculture in Nitra; he concentrated on the ultrastructure of muscle fibres and became head of the Research Institute for Animal Production in Nitra.

In 1965-1993, another assistant of Professor Kolda, MVDr.Oldřich Štěrba (later professor and DrSc.), worked in the Institute of Vertebrate Zoology of the Czechoslovak Academy of Sciences in Brno, re-named the Institute of Systematical and Ecological Biology. He dealt with comparative anatomy and embryology of mammals living in the wild, built an embryological collection, managed and extended the osteological collection and for three years was director of the institute. In 1993 he returned to his original workplace.

When the Faculty of Agriculture was opened in České Budejovice, the former pupils of Professor Kolda went there to teach anatomy, histology and embryology.

Among the direct pupils of Professor Kolda are also two veterinarian histologists to whom Czech veterinary medicine is grateful for the first textbook on veterinary histology, i.e. Professor MVDr.Evžen Novotný, Professor Kolda's successor as head of the Department of Morphology and dean of the Faculty of Veterinary Medicine, and Professor MVDr. Rudolf Böhm CSc. who developed food histology.

We can say that very many assistant professors, professors, scientists and secondary school teachers came from the Anatomical Institute, something that is quite exceptional in veterinary medicine.

After completing his life's deal, Professor MVDr. Jan Kolda left us, but more than anyone else, he is still with us in his work, plans and ideas. What he had begun is maturing in his successors and is being spread further. In the time after World War II the number of personalities of his kind decreased. During the war, and particularly after 1948, they were purposefully suppressed and liquidated. We can only hope that in the new democratic conditions, personalities like Professor Kolda, personalities that the University of Veterinary Medicine had a lot of, will again develop.

NOVOTNÝ E. 1966: Jan Kolda (1895 - 1958) the academician. Historia medicinae veterinariae, Vol. 5. Ústav veterinární osvěty, Pardubice, p. 40, (Compilation of literature before 1965)

CERVENYY C., STEERBA O. 1992: Prof. Jan Kolda, zakladatel Ceskoslovenské veterinární morfologie. /Prof. Jan Kolda, the founder of Czechoslovak veterinary morphology/. Plzeň. lék. Sborn., Suppl. 66:123-124 